\title{
EFFECT OF EDAPHIC FACTORS ON THE DIVERSITY OF VAM FUNGI
}

\author{
Rajan K. Gupta \\ Pt. L.M.S. Government Post Graduate College, Rishikesh (Dehradun) \\ Uttarakhand \\ Corresponding author Email : rajankgupta1@rediffmail.com
}

\begin{abstract}
:
The present study deals with the diversity and distribution of VAMF at different sites with different selected plants. Maximum number of VAMF species were found at site IV (57 species) out of which Glomus species was most dominant (58\%), followed by Acaulospora (19\%), Scutellospora (8\%), Sclerocystis $(4.8 \%)$ and Gigaspora $(1.6 \%)$ respectively. In site II 56 species of VAMF were observed with Glomus (55\%), followed by Acaulospora (22.5\%), Scutellospora $(8 \%)$, Gigaspora $(1.6 \%)$ and Sclerocystis $(3.2 \%)$ respectively. In site III 55 species of VAMF occurred with Glomus (51.6\%) followed by Acaulospora (22.5\%), Scutellospora (9.7\%), Sclerocystis $(4.8 \%)$ and Gigaspora $(0 \%)$ respectively. In site I 54 species of VAMF were found; out of these Glomus was highest 53\% followed by Acaulospora (22.5\%), Scutellospora (5\%), Sclerocystis (1.6\%) and Gigaspora (1.6\%) respectively. These results suggest that selected study sites are rich in VAMF frequency and diversity. The Shanon-Wiever index confirms that diversity of VAMF fungal species varies with the test plant and maximum diversity was observed with Ocimum sanctum (3.948), and Withania somnifera (3.909) respectively. Maximum ANOVA value recorded in case of and Withania somnifera (0.20) and Ocimum sanctum (0.19) respectively. Maximum richness value was observed in case of Ocimum sanctum (0.3948) and Withania somnifera (0.0391).
\end{abstract}

\section{Keywords:}

VAMF, Glomus, Diversity, Mycorrhizae, richness

\section{Introduction:}

Mycorrhizae is the mutualistic symbiosis (non-pathogenic association) between soil borne with the roots of higher plants (Quilambe., 2003), revealed that they are found in wide range of habitats usually in the roots of angiosperms, gymnosperms and pteridophytes. They also occurs in the gametophytes of some mosses, lycopods and psilotes, which are rootless (Mosse et al., 1981; Vyas et al., 2007, 2008). AMF have shown to be potentially able to take up both organic

(Hodge, Campbell \& Fitter, 2001) and inorganic nitrogen from the soil (Govindarajulu et al., 2005). VAM fungi are essential components of ecosystem 
for both re-vegetation of the degraded lands and maintenance of soil structure (Caravaca et al.,2005), therby reducing the risks of erosion and desertification. Soil characteristics, plant species, and climate may all regulate the arbuscular mycorrhizal (AM) fungi community. The distribution of certain VAM fungal species has been related to soil $\mathrm{pH}$, phosphorus level, salinity, soil disturbance (Abbott and Robson 1991), vegetation (Johnson et al., 1992), or hydrologic condition of the soil (Ingham and Wilson, 1999; Miller and Bever, 1999). In general terms, increases in soil $\mathrm{pH}$, nutrient status and salinity in soil are related to a decrease in VAM root colonisation or spore density (Abbott and Robson, 1991). Despite the importance of VAM fungi in the physiology and nutrition of plants, as well as in shaping plant communities (Grime et al., 1987; Van der Heijden et al., 1998; Smith et al,. 1999), factors affecting the presence, diversity, spore density, and root colonisation by AM fungi in soil are poorly understood. One reason is the difficulty of establishing causation from correlation of soil and plant factors with VAM fungal populations. Another reason is that $\mathrm{AM}$ fungi can associate with a wide range of hosts present in community, but the sporulation rates of AM fungi have been found to be host dependent (Bever et al., 1996; Lugo and Cabello, 2002). Host-dependence of VAM fungal population growth rates in soil may play an important role in the maintenance of VAM fungal species diversity in grasslands (Bever et al., 1996), and suppression of mycorrhizal symbioses may result in a decreasing of the dominant plant and an increase in species diversity (Hartnett and Wilson, 1999). In addition, plant diversity may increase or decrease if the dominant plant competitors are more weakly or more strongly mycotrophic than their neighbours (Hartnett and Wilson, 1999). An additional factor influencing populations of VAM fungi in soil, which may in turn affect the performance of plant species relative to each other, is the hydrologic condition of the soil, which may vary seasonally. The hydrologic condition of the soil plays an important role in determining plant community structure, and this effect is even more important when soils are commonly subjected to periods of dryness 
and flooding (Chaneton et al., 1998). VAM fungi have been found in the roots of many plants in wetlands (Ingham and Wilson, 1999; Miller and Bever (1999), or salt marshes (Brown and Bledsoe 1996). This is relevant because the fungi are believed to require wellaerated soils, and are thought to have problems adapting to flooded conditions (Mosse et al., 1981). Nevertheless, little is known of VAM fungi patterns in wetlands or of the influence of the hydrologic condition of the soil on populations of AM fungus species. The most important and historical account of medicine in the form of "Ayurveda"(2500 t0 900 B.C.), which is considered as "Upaveda" ,Charak Samhita and Susruta Samhita" also

delt with plants related to medicine and their use in health management.These days many people cultivating medicinal plants to fulfil the increasing demands of pharmaceutical industries. The major biochemical constituents of Ashwagandha (is a small, woody shrub in the Solanaceae family) that root are steroidal alkaloids and steroidal lactones in a class of constituents called withanolides. At present, 12 alkaloids, 35 withanolides, and several sitoindosides from this plant have been isolated and studied. A sitoindoside is a withanolide containing a glucose molecule at carbon 27. Much of ashwaganda\'s pharmacological activity has been attributed to two main withanolides, withaferin A and withanolide D. Tulsi, Queen of Herbs, the legendary $\backslash$

\section{Material and Method:}

For the present investigation two test sites were selected, (I) Kariaya Village (II) Jaitpur Village. The experiments were conducted for quantitative and qualitative estimation of AM fungi were done from rhizosphere and nonrhizosphere soil and roots of test plants. The rhizosphere soil and root samples of selected test medicinal plants were collected from study sites up to 0-10, 10$20,20-30,30-40 \mathrm{~cm}$ depth. The VAM spores were isolated from the collected soil samples by wet sieving and decanting method (Gerdemann and Nicolson, 1963). Mycorrhizal spores are identified according to their spore morphology by 
conventional taxonomic key of Schenck and Perez (1990\&http:/www.invam.cat.wu.edu). For the estimation of AM spores, a technique provided by Gour and Adholeya (1994) was followed. The soil pH was determined in 1:5 suspension of soil; deionized water ratio, electrometrically by glass electrode $\mathrm{pH}$ meter 335 (Jackson, 1982). Statistical analysis of data for comparison of means, analysis of variance (ANOVA), etc. was followed after Gupta and Kapoor (1997).

\section{Result and Discussion:}

The result obtained from the present study depicted in the table 1, which show the relative abundance of VAMF spores associated with test plants Withania somnifera and Ocimum sanctum, growing in the Karaiya village and Jaitpur village. Variance in relative abundance (RA) of VAMF spores along with the depths of the soil was observed. Maximum value recorded of VAMF spores was observed from the soil surface up to $10 \mathrm{~cm}$ length and it reduces and minimum was recorded at 30-40 $\mathrm{cm}$ depth. Shannon-Weaver diversity index and evenness of VAM fungi is shown in table (2). The Shannon-Weaver index value suggests that W. somnifera harbours more diverse morphotypes of O. sanctum. Comparatively soil of Jaitpur village has fairly greater number of morphotypes in W. somnifera then in the soil of Karaiya, H 2.351 and H 2.250 respectively. However, Shannon -Weaver index $\left(\mathrm{H}^{\prime}\right)$ values confirm that (VAMF) reduces whereas in contrast $\mathrm{H}^{\prime}$ value obtained from the different depth of rhizosphere of O. sanctum growing in Jaitpur village soil showed to maximum value at the depth of 10-20 cm (2.143), and further deeper region showed linear decrease an $\mathrm{H}^{-}$value. However, O. sanctum growing Karaiya village showed maximum $\mathrm{H}^{-}$value up to $10 \mathrm{~cm}$ depth and below this $\mathrm{H}^{-}$value gradually decreased The value obtained for evenness $\left(\mathrm{J}^{\prime}\right)$ of VAMF with W. somnifera growing in Karaiya or Jaitpur village soil are also described in table (2). Interestingly there is little hike in $\mathrm{J}^{-}$value at $20-30 \mathrm{~cm}$ and $30-40 \mathrm{~cm}$ deep in respectively with $\mathrm{W}$. somnifera plants growing in Jaitpur village soil. However, same species growing 
at Karaiya village dose not show any significant difference in $\mathrm{J}^{`}$ value. Evenness of VAMF $J^{\prime}$ value of O.sanctum in both the sites Karaiya village soil and Jaitpur village soil showed poorly different trend. At Kariaya village soil $\mathrm{J}$ 'value almost remains same upto $30 \mathrm{~cm}$ depth, but suddenly significant reduction in $\mathrm{J}^{`}$ value was observed. In contrast to this Jaitpur village soil though $\mathrm{J}^{\prime}$ value remains same upto the depth of $30 \mathrm{~cm}$ but a significant increase in $\mathrm{J}^{-}$value at $40 \mathrm{~cm}$ depth was recorded. During the present study, a total of 27 morphologically distinct VAM species were isolated from the rhizosphere of Withania somnifera and Ocimum sanctum growing at two different sites; Karaiya village and Jaitpur village (Fig.1). Out of 27 VAM fungal species, 13 different species were found associated only with W. somnifera, six species were found only with $O$. sanctum and eight species were found common in both the plants. Thus, a total of 21 species associated with W. somnifera and

14 species were found associated with O. sanctum. Among the 21 VAM species found associated with W. somnifera, five VAMF species viz. Acaulospora mellea, A. scrobiculata, Glomus claroideum, G. etunicatum and G. macrocarpum were not found in Jaitpur soil, whereas A. bireticulata, A. denticulata, G. dimorphicum were not found in Jaitpur village soil (Fig. 2). Acaulospora sp., A. nicolsonii, G. clarum and G. hoi were the prominent species of the VAM fungi which were isolated from surface to $40 \mathrm{~cm}$. depths in the Karaiya village soil. G. intraradices and G. mosseae were isolated from the depth of $30 \mathrm{~cm}$. A. denticulata and Glomus sp. were obtained from the depths of 10-20 and 20-30 cm. G. ambisporum, and G. fasciculatum were isolated from 0-10 and 10-20 cm depths. A. bireticulata, G. australe, G. desrticola, G. dimorphicum, and G. pustolatum were isolated from $0-10 \mathrm{~cm}$ depth in the Karaiya village soil (Table 1). In the Jaitpur village soil, A. nicolsonii, G. clarum, G. hoi and G. intraradices were isolated from the topsoil to of $40 \mathrm{~cm}$ depth. G. etunicatum, G. mosseae and G. versiforme were collected from of $30 \mathrm{~cm}$ depth. A. mellea and G. desrticola were isolated from 0-10, 10-20, and 30-40 cm soil depth. A. scrobiculata, G. australe, G. fasciculatum, G. macrocarpum, and G. 
pusotlatum were isolated from 0-10 and 10-20 cm depth. Acaulospora sp. and Glomus sp. were isolated from 0-10 and 20-30 cm depth. G. ambisporum was isolated only $10-20 \mathrm{~cm}$ (Table 1). Out of 27 VAMF species, 14 species were found associated with $O$. sanctum in both the sites (Fig. 1). Among the 14 VAMF species, three species viz. A. foveata, Entrophospora infrequens and G. etunicatum were not found in Karaiya village soil (Fig. 2). A. nicolsonii and G. clarum were the two VAMF species found very prominent in Karaiya village soil and isolated in all measured soil depth. A. spinosa, G. fasciculatum, G. heterosporum and $\mathrm{G}$. hoi were isolated from the depth of $30 \mathrm{~cm}$. Whereas, A. scrobiculata, G. ambisporum and G. intraradices were isolated from the depth of $20 \mathrm{~cm}$. G. botryoides was isolated in topsoil $(0-10 \mathrm{~cm})$ and Scutellospora pellucida was isolated from $20-30$ and $30-40 \mathrm{~cm}$ soil depth (Table 1). In Jaitpur village soil G. clarum, G. fasciculatum and G. intraradices were isolated from $40 \mathrm{~cm}$ depth. A. nicolsonnii, G. heterosporum and G. hoi were collected from $30 \mathrm{~cm}$ depth while, A. foveata, G. ambisporum and G. etunicatum $20 \mathrm{~cm}$ depth. A. spinosa was isolated from 10-20, 20-30 and 30-40 cm soil depths, respectively. Here, also G. botryoides was isolated from the topsoil. E. infrequens was isolated from $20-30$ and $30-40 \mathrm{~cm}$ depth and S. pellucida was isolated from $30-40 \mathrm{~cm}$ depth (Table 1). The result shown in fig. 3 clearly indicate that 14 VAMF species associated with $\mathrm{W}$. somnifera, commonly occurring in both the sites Karaiya village soil as well as Jaitpur village soil. Among 14 VAMF species, 11 species associated with O. sanctum. It was also observed that 6 VAMF species viz. A. nicolsonii, G. ambisporum, G. clarum, G. fasciculatum, G. hoi and G. intraradices were found associated with both the test plants at in both the sites. However, three species A. bireticulata, A. denticulata and G. desrticola which are associated with W. somnifera were found only in Karaiya village soil. A linear regression analysis with coefficient of determination $(=$ squared correlation coefficient or $\mathrm{r} 2)$ of VAMF spore population with soil depth, soil $\mathrm{pH}$, and soil moisture per cent in $\mathrm{W}$. somnifera and $O$. sanctum at both the sites were presented in fig. 4 (A-F) and fig. 5 (A-F). 
It is clearly evident from the result that the VAMF spore population showed a strong negative correlation with soil depth, $\mathrm{pH}$ and moisture of the soil. It is assumed that an increase in single variable (depth $\mathrm{pH}$, or moisture) resulted in decrease in VAMF spore population in both the test plants at both the sites. In Karaiya village soil, depth and moisture of rhizosphere soil of both the test plants show highly significant correlation, while, variation found in correlation between soil $\mathrm{pH}$ and spore population of both the plants. Here, VAMF spore population had weak correlation $(\mathrm{r} 2=0.563)$ with the $\mathrm{pH}$ of rhizosphere soil with W. somnifera in comparison to O. sanctum ( $\mathrm{r} 2=0.943)$. Whereas, in Jaitpur village soil, VAMF spore population showed similar trend as observed at Karaiya village soil with the depth and percent moisture of rhizosphere of both the plants. These two attributes significantly, correlated with the VAMF spore population (Fig. $5 \mathrm{~A}-\mathrm{F}$ ). The data presented in table (3) show the comparative analysis of average values of soil $\mathrm{pH}$, soil moisture, VAMF spore population and Shannon-Weaver diversity index at four soil depths from both the sites. The mycorrhizal population dropped significantly from the upper to lower soil depth level. Both the soils showed similar relationships for depths and mean total spore population (Fig. 6). In the present study average soil moisture present initially increased two fold with the increasing depth (Fig. 7). Average soil $\mathrm{pH}$ found increased. Interestingly, soil $\mathrm{pH}$ values showed a general tendency to increase with increasing soil depth in both the site (Fig.8).

\section{Discussion:}

In the present study, the rhizosphere of two medicinal plants viz. Withania somnifera and Ocimum sanctum in different soil depth at two locations showed common as well as variant VAMF flora. Such variations in the VA mycorrhizal fungal community at differ

\section{Conclusion:}

This study shows that the frequency of genera and species of VA mycorrhizal fungi isolated from both the site varied with the above ground vegetation and with changes in soil moisture and soil $\mathrm{pH}$. Currently, we have limited means 
for accurately determining the complex of genera and species that forming symbiosis with host plants in natural soil and that are responsible for variations in fungal density obtained from soil samples. Recent advancements in characterizing mycorrhizae with molecular markers will greatly improve our understanding of the ecology of these fungi.

\section{Acknowledgement:}

Authors are thankful to Head, Department of Botany, Dr. H.S. Gour University, Sagar, RKG thankfully acknowledge UGC \& UCOST for financially assistance.

\section{Reference}

Abbott, L. \& A.Robson. 1991. Factors influencing the occurrence of vesiculararbuscular mycorrhizas. Agric Ecosyst Environ 35: 121-150

An, Z.Q., J.H. Grove, J.W. Hendrix, D.E. Hershman \& G.T. Henson .1990. Vertical distribution of endogonaceous mycorrhizal fungi associated with soybean, as affected by soil fumigation. Soil Biology and Biochemistry 22: 715-719.

Bagyaraj D.J. 1991. Ecology of vesicular-arbuscular mycorrhizae. In: Arora DK, Rai B, Mukerji KG, Knudsen GR. eds. Handbook of applied mycology: Soil and plants vol. I. Marcel Dekker, Inc., New York, New York. Pp. 3-34.

Bever, J., J.Morton, J.Antonovics \& P.Schultz .1996. Host-dependent sporulation and diversity of arbuscular mycorrhizal fungi in a mown grassland. J Ecol 84:71-82

Bever, J.D., P.A. Schultz, A.Pringle \& J.B. Morton. 2001. Arbuscular mycorrhizal fungi: more diverse than meets the eye, and the ecological tale of why. Bioscience 51: 923-931.

Brown, A.\& C.Bledsoe. 1996. Spatial and temporal dynamics of mycorrhizas in Jaumea carnosa, a tidal saltmarsh halophyte. J Ecol 84:703-715 
Caravaca, F., M.M. Alguacil, J.M. Barea \& A.Roldan. 2005.Survival of inocula and native AM fungi species associated with shrubs in degraded Mediterranean ecosystem. Soil Biol. Biochem. 37:227-233

Daniels, B.A. \& J.M. Trappe. 1980. Factors affecting spore germination of the vesicular-arbuscular mycorrhizal fungus, Glomus epigaeus. Mycologia 72: 457-471.

Douds, D.D., L. Galvez, R.R. Janke \& P.Wagoner. 1995. Effects of tillage and farming systems upon populations and distribution of vesicular arbuscular mycorrhizal fungi. Agriculture, Ecosystems and Environment 52: $111-118$.

Dubey, A. 2006. Studies on diversity of AM fungi with special reference to rice crop. Ph.D. Thesis, Dr. H. S. Gour University, Sagar (M.P.) India.

Dwivedi, O.P.,, R.K. Yadav, D. Vyas \& K.M. Vyas. 2004. Role of potassium on the occurrence of vesicular arbuscular mycorrhizal spores in the rhizosphere of Lantana sp. In; Microbiology and Biotechnology for sustainable developments (Ed.) P.C. Jain, CBS Publishers and distributors, New Delhi 248-253. ecosystem variability and productivity. Nature 396:69-72

Friese, C.F. \& R.E. Koske .1991. The spatial dispersion of spores of vesiculararbuscular mycorrhizal fungi in a sand dune: micro-scale patterns associated with the root architecture of American beach grass. Mycological Research 95: 952-957.

Gerdemann J.W.\& T.H. Nicolson. 1963. Spores of mycorrhizal Endogone species extracted from soil by wet sieving and decanting. Transactions of the British Mycological Society 46:235-244.

Gour A. \& A. Adholeya. 1994. Estimation of VAMF spores in soil: A modified method. Mycorrhiza News 6: 10-11.

Govindarajulu, M., P.Pfeffer, H.R. Jin, J. Abubaker, D.D. Douds, J.W. Allen, H. Bucking, P.J. Lammers and Y.Shachar-Hill .(2005). Nitrogen transfer in the arbuscular mycorrhizal symbiosis. Nature 435: 819-823. 
Green, N.E., S.O. Graham and N.C.Schenck. 1976. The influence of pH on the germination of vesicular-arbuscular mycorrhizal spores.Mycologia 68: 929- 934

Grime, J.P., J.M. Mackey, S.M. Hillier and D.J. Read. 1987. Floristic diversity in a model system using experimental microcosms.Nature 328:420-422

Guadarrama, P. and F. Alvarez-Sanchez .1999. Abundance of arbuscular mycorrhizal fungi spores in different environments in a tropical rain forest, Veracruz, Mexico. Mycorrhiza 8: 267-270.

Gupta S.C.and V.K. Kapoor. 1997. Fundamentals of applied statistics (III ed) S Chand and Sons. New Delhi.

Hartnett, D. and G. Wilson. 1999. Mycorrhizae influence plant community structure and diversity in tallgrass prairie. Ecology 80:1187-1195

Hodge, A., C.D. Campbell, and A.H. Fitter. (2001). An arbuscular mycorrhizal fungus accelerates decomposition and acquires nitrogen directly from organic material. Nature 413: 297-299

Ingham, E. and M. Wilson .1999. The mycorrhizal colonization of six wetland species at sites differing in land use history. Mycorrhiza 9:233-235

Jackson M.L. 1967. Soil Chemical Analysis. Prentice Hall of India (Ltd.) New Delhi, pp. 428.

Jakobsen, I. and N.E. Nielsen. 1983. Vesicular arbuscular mycorrhiza in fieldgrown crops I. Mycorrhizal infection in cereals and peas at various times and soil depths. New Phytologist 93: 401-413.

Jansa, J.A., A. Mozafar, T. Anken, R. Ruh, I.R. Sanders and E. Frossard .2003. Soil tillage affects the community structures of mycorrhizal fungi in maize roots. Ecological Applications 13: 1164-1176.

Johnson, N.C., D.Tilman and D. Wedin .(1992). Plant and soil controls on mycorrhizal fungal communities. Ecology 73:2034-2042

Kabir, Z., I.P. O\'Halloran, P. Widden and C.Hamel .1998. Vertical distribution of arbuscular mycorrhizal fungi under corn (Zea mays L.) in no-till and conventional tillage systems. Mycorrhiza 8: 53-55. 
Lugo M.A. and M.N. Cabello. 2002. Native arbuscular mycorrhizal (AMF) from mountain grassland (Córdoba, Argentina) I. Seasonal variation of fungal spore diversity. Mycologia 94:579-586

Mader, P., A. Fliessabach, D. Dubois, L. Gunst, P. Fried and U. Niggli. 2002. Soil fertility and biodiversity in organic farming. Science 296: 1694-1697.

Miller, S. and J. Bever .1999. Distribution of arbuscular mycorrhizal fungi in stands of the wetland grass Panicum hemitomon along a wide hydrologic gradient. Oecologia 119:586-592

Mosse, B., D. Stribley and F. Le Tacon. 1981. Ecology of mycorrhizas and mycorrhizal fungi. In: Alexander $M$ (ed) Advances in microbial ecology. Plenun Press, New York, pp 137-210

Mosse, B., D.P. Stribley and F. Tacon . (1981).Ecology of mycorrhizae and mycorrhizal fungi Oehl, F., E. Sieverding, K. Ineichen, E.A. Ris, T. Boller \& A. Wiemken. 2005. Community structure of arbuscular mycorrhizal fungi at different soil depths in extensively managed agroecosystems.NewPhytologist 165: 273-283.

Oehl, F., E. Sieverding, K. Ineichen, P. Mader, D Dubos, T Boller and A. Wiemken .2004. Impact of long-term conventional and organic farming on the diversity of arbuscular mycorrhizal fungi. Oecologia 138: 574-583

Oehl, F., E. Sieverding, K. Ineichen, P. Mader, T. Boller \& A. Wiemken. 2003. Impact of land use intensity on the species diversity of arbuscular mycorrhizal fungi in agroecosystems of central Europe. Applied and Environmental Microbiology 69: 2816-2824.

Peat, H.J.\& A.H. Fitter.1993. The distribution of arbuscular mycorrhizas in the British flora. New Phytologist 125: 845- 854.

Powell, C.L. \& D.J. Bagyaraj 1984. VA-Mycorrhiza. CRC Press, Boca Raton, Florida. pp. 234. Quilambo, O.A. (2003). The vesicular- arbuscular mycorrhizal symbiosis. African J.Biotechnol. 2:539-546

Read D.J. 1989. Mycorrhizas and nutrient cycling in sand dune ecosystems. Proceedings of the Royal Society of Edinburgh, 96: 89-110. 
Redhead J.F. 1977. Endotrophic mycorrhizas in Nigeria: Species of the Endogonaceae and their distribution. Transactions of the British Mycological Society 69: 275-280.

Rillig, M.C. and C.B. Field. 2003. Arbuscular mycorrhizae respond to plants exposed to elevated atmospheric $\mathrm{CO} 2$ as a function of soil depths. Plant and soil 254: 383-391.

Schenck N.C. and Y. Perez. 1987. Manual for identification of VAM fungi. Synergistic Pub. Gainesville. Fl., U.S.A.

Schenck, N.C., and R.A. Kinloch 1980. Incidence of mycorrhizal fungi on six field crops in monoculture on a newly cleared woodland site. Mycologia 72: 445-455.

Schwab, S. and F.B. Reeves . 1981. The role of endomycorrhizae in revegetation practices in the semi-arid West. III. Vertical distribution of vesiculararbuscular (VA) mycorrhiza inoculum potential. American Journal of Botany 68: 1293-1297.

Sharma, S.K., G.D. Sharma and R.R.Mishra. 1986. Status of mycorrhizae in sub-tropical forest ecosystem of Meghalaya. Acta Botanica Indica 14: 8792.

Smith T.F. 1978. A note on the effect of soil tillage on the frequency and vertical distribution of spores of vesicular-arbuscular endophytes. Australian Journal of Soil Research 16: 359- 361.

Smith, M., D.Hartnett and G.Wilson. 1999. Interacting influence of mycorrhizal symbiosis and competition on plant diversity in tallgrass prairie.

Oecologia 121:574-582

Sparling, G.P. and P.B.Tinker 1975. Mycorrhizae in Pennine grassland. In: Sanders FE, Mosse B, Tinker PB. eds. Endomycorrhizae., Proceedings of a Symposium held at the University of Leeds, 22-25 July 1974, Academic Press, New York, New York, Pp. 545-560.

Sutton, J.C. and G.L. Barron .1972. Population dynamics of Endogone spores in soil. Canadian Journal of Botany 50: 1909-1914. 
Tamuli, P. and P.Boruah. 2002. VAM association of agar wood tree in Jorhat district of the Brahmaputra valley. Indian Forester 128 (9): 991-994.

Thompson J.P. 1991. Improving the mycorrhizal infection of the soil through cultural practices and effects on growth and phosphorous uptake by plants. In: Johansen C, Lee KK, Sahrawat KL, eds. Phosphrous nutrition of grain legumes in the semi-arid tropics. Pantancheru, India: International Crops Research Institutes for the Semi-arid Tropics, 117138.

Trinick M.J. 1977. Vesicular arbuscular infection and soil phosphorus utilization in Lupinus spp. New Phytologist 78: 297-304.

Van der Heijden, M.G.A., J.N. Kilronomos, M.Ursic, P.Moutoglis, R.StreitwolfEngel, T.Boller, A.Wiemken and I.R. Sanders. 1998. Mycorrhizal fungal diversity determines plant biodiversity, Vyas, D., \& A.Soni 2004. Diversity and distribution of VAMF in the seminatural grassland. Indian Journal of Ecology 31: 170-171

Vyas, D., A. Dubey, A. Soni, M.Mishra and P. Singh. (2007). Arbuscular mycorrhizal fungi in early land plants. Mycorrhiza News.19(2)

Vyas, D., P. Singh, M. Mishra, and A. Dubey. (2008). VA Mycorrhizal Association in Weeds of Seminatural Grassland of Sagar. Indian J. Agroforestry 10(2): 91-97

Vyas. D., A. Dubey, P.K.Singh, M.K. Mishra, A. Soni and P.Soni .2006a. VA mycorrhizal fungi in tropical monsoonic grassland. Journal of Basic and Applied Mycology 5 (I\&II): 78-81.

Wang, G., D.P. Stribley, P.B. Tinker and C.Walker. 1993. Effects of pH on arbuscular mycorrhiza I. Field observations on the long-term liming experiments at Rothamstead and Woburn. New Phytologist 124: 465472.

Warcup J.H. 1951. Soil-streaming: a selective method for the isolation of fungi of Ascomycetes from soil. Transactions of the British Mycological Society 34: 515-518. 